\title{
Effects of bypass fat on postpartum reproductive performance in dairy cattle
}

\author{
Surendar Singh Nirwan, Jitendra Singh Mehta, Ashok Kumar, Pramod Kumar, Arvind Kumar and Vikramjit Singh
}

Received: 14 November 2018 / Accepted: 02 February 2019 / Published online: 18 April 2019

(c) Indian Dairy Association (India) 2019

\begin{abstract}
This study was conducted to determine the effects of bypass fat on postpartum reproductive performance in dairy cattle. A total of 40 advance pregnant crossbred dairy cows of $2^{\text {nd }}$ to $5^{\text {th }}$ parity were randomly divided into two groups, control $(\mathrm{n}=10)$ and treatment $(\mathrm{n}=30)$. The control animals were maintained on routine standard feeding schedule. The treatment animals in addition to routine standard feeding schedule, were supplemented orally daily with extra $100 \mathrm{~g}$ of bypass fat (Enerfat, Kemin) for about 2 weeks before expected date of calving and continued one week after calving. The level of bypass fat was then increased as per the milk production@10 gram per litre of milk produced until 60 days postpartum limiting to maximum of 250 gram/day. Blood samples were collected from each animal at 2 week prior to expected date of calving (-14), day $0,10,20$ and 30 of calving, for the estimation of various blood biochemical parameters. Gross uterine involution and the interval from calving to first estrus occurrence were recorded. Bypass supplementation non-significantly reduce uterine involution time and time from calving to first postpartum observed estrus. Peripartum bypass fat supplementation significantly $(\mathrm{P}<0.05)$ increased serum glucose and total cholesterol but significantly $(\mathrm{P}<0.05)$ decreased serum (non-esterified fatty acids) NEFA level.
\end{abstract}

Surendar Singh Nirwan $(\bowtie)$, Jitendra Singh Mehta, Ashok Kumar, Pramod Kumar, Arvind Kumar

Department of Veterinary Gynaecology and Obstetrics,

College of Veterinary and Animal Science, Rajasthan University of

Veterinary and Animal Sciences, Bikaner-334 001, Rajasthan, India

E-mail: surendarnirwan@gmail.com; Phone: 8290344766

Vikramjit Singh

Department of Livestock Production Management,

College of Veterinary and Animal Science, Rajasthan University of

Veterinary and Animal Sciences, Bikaner-334 001, Rajasthan, India
Keywords: Bypass fat, Cholesterol, NEFA, Serum glucose, Uterine involution

\section{Introduction}

The peak milk production, at about 5-8 weeks postpartum occurs earlier than maximum feed consumption causing cows to be in negative energy balance and to mobilize fat from adipose tissue in early lactation (Bell, 1995; Rukkwamsuk et al., 1998; Miyoshi et al., 2001 and Gutierrez et al., 2009). Negative energy balance may also be the main cause of late uterine involution and cleansing process due to atony or hypotony of uterus (Kaczmarowski et al., 2006). Recent understandings of the role of fats in metabolism open new opportunities for improving production, health, and reproduction in cattle. Inclusion of fats in the diet during peripartum period has improved reproductive performance (Thatcher et al., 2006; De Veth et al., 2009), improved energy balance (von Soosten et al., 2012), reduced the incidence of metabolic diseases, and allowed energy density to be maintained in diets without increasing the use of rapidly fermentable carbohydrates.

Role of the bypass fat in the rations of the high producing dairy animals is very crucial for enhancing the energy density of ration (National Research Council, 2001). Feeding bypass fat to high producing lactating cows can enhance energy density of ration and energy intake in early lactation without compromising rumen cellulolytic bacterial activity (Jenkins and Palmquist, 1984). Thus, the deleterious effect of acute negative energy balance on lactation can be avoided.

\section{Materials and methods}

\section{Experimental location and animals}

The present investigation was carried out in the department of Veterinary Gynaecology and Obstetrics, CVAS, Bikaner and at a organized dairy farm in Bikaner. A total of 40 advance pregnant Holstein Friesian crossbred dairy cows of $2^{\text {nd }}$ to $5^{\text {th }}$ parity were utilized in the study. The animals selected for the study were diagnosed with advanced pregnancy through breeding records and gynaeco-clinical examinations. 


\section{Management of the animals}

All the pregnant cows were maintained in well ventilated hygienic sheds and were fed green fodder, hay and compounded concentrate mixture, as per standard feeding schedule. These animals were maintained under identical nutritional, hygienic and management conditions. Fresh tap water was available adlib to all the cows. All the cows were milked by milking machine twice daily at 5.30 A.M and 5.30 P.M and the amount of milk produced by each cow was recorded. The calves were weaned just after birth.

\section{Experimental design}

The experimental cows $(\mathrm{n}=40)$ were randomly divided into two groups, control $(\mathrm{n}=10)$ and treatment $(\mathrm{n}=30)$. The control animals were maintained on routine standard feeding schedule. The treatment animals in addition to routine standard feeding schedule were supplemented orally daily with extra $100 \mathrm{~g}$ of bypass fat (Enerfat, Kemin) for about 2 weeks before expected date of calving and continued one week after calving. The level of bypass fat was then increased as per the milk production@10 gram per litre of milk produced (Gowda et al., 2013) until 60 days postpartum limiting to the maximum of 250 gram/day.

\section{Evaluation of gross uterine involution}

The evaluation of gross uterine involution was carried out daily by per- rectal palpation from day 10 postpartum until complete involution or up to day 45 postpartum which ever was earlier.

The criteria used to determine uterine involution were (1) return of the uterus to normal location in the pelvic cavity, (2) normal and approximately equal size of the uterine horns and (3) normal uterine tone and consistency (Morrow et al., 1966).

\section{Observation of first postpartum estrus}

As routine management the postpartum cows were observed twice a day for the occurrence of estrus, based on vaginal discharges and behavioural signs. Further, the occurrence of estrus was confirmed by gynaeco-clinical examination of genitalia and the interval from calving to first estrus occurrence was recorded.

\section{Blood sample collection}

Blood samples were collected from each animal by jugular vein puncture in sterile vials. The serum was separated immediately after the collection by centrifugation of blood samples for 10 minutes at $3000 \mathrm{rpm}$. The serum was stored in sterilized plastic storage vials at $-20^{\circ} \mathrm{C}$ until analyzed for various blood biochemical parameters.

\section{Estimation of blood biochemical parameters}

The parameters like blood glucose, total cholesterol, nonesterified fatty acids, calcium and phosphorus were estimated using standard procedure and assay kits procured from Coral Clinical Systems, Goa, with the help of digital spectrophotometer and Serum NEFA concentration was estimated by Elisa kit procured from Shanghai Yehua Biological Technology Co., Ltd.

\section{Statistical analysis}

Data were collected, arranged, summarized and then statistically analyzed. The data were analysed using conventional procedures as described previously (Snedecor and Cocharan, 1994).

\section{Results and discussion}

\section{Uterine involution}

The mean duration taken for uterine involution following calving in control group and bypass fat supplemented cows was $23.6 \pm 0.40$ and $22.4 \pm 0.29$ days, respectively (Table 1 ). In the present study, the average number of days required for uterine involution post calving in treatment groups $(22.4 \pm 0.29)$ was non- significantly different than control group (23.6 \pm 0.40$)$. The findings are in close agreement with report of Khalil et al. (2012) and Theodore et al. (2016).

\section{First estrous postpartum}

The mean duration taken for exhibition of first postpartum estrus by control group and treatment group was $35.2 \pm 1.25$ and $33.13 \pm 0.53$ days, respectively (Table 1 ). The mean number of days taken for exhibition of first postpartum estrus was nonsignificantly different in control group cows than treatment group cows. The present findings are in agreement with the study of Son et al. (2000), McNamara et al. (2003), Shelke et al. (2012b) and Khalil et al. (2012).

\section{Non-esterified fatty acids}

The mean serum NEFA ( $\mu \mathrm{mol} / \mathrm{l}$ ) level during peripartum periods in the control and treatment group cows are presented in table 2. The overall mean level of NEFA was significantly $(\mathrm{P}<0.05)$ lower in treatment group than control group. The mean NEFA level varied significantly $(\mathrm{P}<0.05)$ between the groups on the day of calving and day 10 postpartum but on other stages varied nonsignificantly. In control group, serum NEFA level was significantly higher at calving than peripartum level and then reached significantly lower level on day 10 postpartum and then decreased non-significantly on day 20 and 30 postpartum to reach a nadir of $274.84 \pm 3.62 \mu \mathrm{mol} / \mathrm{l}$. In the treatment group the trend was same but serum NEFA level was significantly decrease on day 10 and 20 postpartum and then fluctuated non-significantly to reach a nadir of $239.14 \pm 2.9 \mu \mathrm{mol} / \mathrm{l}$. 
In the present study, the overall mean level of NEFA was significantly $(\mathrm{P}<0.05)$ lower in treatment group than control group. The results of the present study are corroborate with reports of Tyagi et al. (2009), Singh et al. (2014), Rajesh et al. (2014) and Yadav et al. (2015). In the present study, serum NEFA level was significantly higher on day of calving than prepartum level in both the groups and then subsequently decreased on postpartum intervals and reached at lowest value on day 30 postpartum. The findings were in line with the findings of Drackley (2000), Cerri et al. (2009), Galvao et al. (2010), Giuliodori et al. (2011), Garverick et al. (2013), yadav et al. (2015) and Theodore et al. (2017).

\section{Blood glucose}

The mean blood glucose level during peripartum periods in the control and treatment group cows are presented in table 3.

The mean blood glucose value spiked up $(\mathrm{P}<0.05)$ to reach an apex of $64.80 \pm 1.14 \mathrm{mg} / \mathrm{dl}$ on the day of calving and reduced back to normal levels on the 10 th day postpartum. The values, thereafter, were found to be fluctuating non-significantly between other postpartum intervals. A similar trend was also observed in treatment group, with the highest $(\mathrm{P}<0.05)$ mean glucose concentration of $67.63 \pm 0.56 \mathrm{mg} / \mathrm{dl}$ on the day of calving then fluctuating non-significantly day 10 and 20 postpartum but mean serum glucose level on day 30 postpartum significantly differed from prepartum, at calving, day 10 and 20 postpartum level. While comparing the group-wise overall mean blood glucose concentrations of the cows, it was observed that the cows supplemented with bypass fat were having significantly $(\mathrm{P}<0.05)$ higher glucose value than the control cows $(59.37 \pm 0.48$ vs. $57.07 \pm 0.75 \mathrm{mg} / \mathrm{dl})$. There was significantly higher $(\mathrm{P}<0.05)$ mean serum glucose level in treatment groups then control group at all the stages during both pre and postpartum period studied.
In the present study, the overall group wise mean blood glucose concentration was found significantly higher $(\mathrm{P}<0.05)$ in treatment group than control group ( $59.37 \pm 0.48$ vs. $57.07 \pm 0.75 \mathrm{mg} / \mathrm{dl})$. The results are in agreement with the findings of Waghmare et al. (2016) and Theodore et al. (2017), which can be attributed to the effect of bypass fat supplementation in the diet of treatment group. The other possible reason could be the glycolysis of sugar which might have inhibited by supplementation of bypass fat in order to improve their energy levels (Goff et al., 1996; Mc Namara and Valdez, 2005, Zhang et al., 2011 and Waghmare et al., 2016).

Stage variations in mean glucose level within groups are in partial agreement with Yadav et al. (2015) and Theodore et al. (2017).

The significantly higher mean blood glucose concentration obtained on the day of parturition in the present study corroborated with the observations of Sato (1978), Ghosh et al. (1991), Hadiya (2006), Garverick et al. (2013), Yadav et al. (2015) and Theodore et al. (2017) as they also noted the highest blood glucose concentration at parturition. The researchers suggested that in response to physiological stimuli, glucocorticoid releases at calving and causes rise in blood glucose level due to gluconeogenesis. The fall in glucose levels after parturition could be due to high demands for lactose synthesis for milk production and insufficient gluconeogenesis (Doepel et al., 2002) because energy losses could not be fully compensated by energy intakes (Yadav et al., 2015). The lower fall in glucose after parturition in treatment group than control might be due to bypass fat supplementation. However, some studies reported nonsignificant effect on blood glucose level on bypass fat supplemented group (Fahey et al., 2002; Singh et al., 2014 and Wadhwa et al., 2012).

Table 1 Mean time duration for $1^{\text {st }}$ postpartum estrus and gross uterine involution

\begin{tabular}{llc}
\hline Parameter & Control $(\mathrm{n}=10)$ & Treatment $(\mathrm{n}=30)$ \\
\hline Days to gross uterine involution. & $23.6 \pm 0.40$ & $22.4 \pm 0.29$ \\
$1^{\text {st }}$ estrus observed postpartum (days) & $35.2 \pm 1.25$ & $33.13 \pm 0.53$ \\
\hline
\end{tabular}

Table 2 Serum NEFA level $(\mu \mathrm{mol} / \mathrm{l})(\mathrm{mean} \pm \mathrm{SE})$ during peripartum period

\begin{tabular}{llc}
\hline Days pre-and postpartum & Serum NEFA $(\mu \mathrm{mol} / \mathrm{l})$ & Treatment $(\mathrm{n}=30)$ \\
\cline { 2 - 3 } & Control $(\mathrm{n}=10)$ & $332.52 \pm 6.26^{\mathrm{b}}$ \\
\hline-14 & $313.30 \pm 6.64^{\mathrm{b}}$ & $498.34 \pm 3.25^{\mathrm{dB}}$ \\
0 & $567.28 \pm 6.09^{\mathrm{dA}}$ & $340.75 \pm .5 .24^{\mathrm{cB}}$ \\
10 & $372.42 \pm 4.88^{\mathrm{aA}}$ & $249.78 \pm 3.14^{\mathrm{a}}$ \\
20 & $281.36 \pm 4.47^{\mathrm{a}}$ & $239.14 \pm 2.9^{\mathrm{a}}$ \\
30 & $274.84 \pm 3.62^{\mathrm{a}}$ & $332.10 \pm 12.14^{\mathrm{B}}$ \\
overall & $361.84 \pm 15.64^{\mathrm{A}}$ & \\
\hline
\end{tabular}

Note: Means having different superscripts (capital letter) within a row differ significantly $(\mathrm{P}<0.05)$.

Means having different superscripts (small letter) within a column differ significantly $(\mathrm{P}<0.05)$. 
The mean blood glucose levels found in both the groups were within the normal limit $(42-75 \mathrm{mg} / \mathrm{dl})$ and concurred with the findings of Kumar (2000), Sivaraman et al. (2002) and Arieli et al. (2008).
The mean blood glucose level in the treated cows was significantly $(\mathrm{P}<0.05)$ higher $(59.37 \pm 0.48 \mathrm{mg} / \mathrm{dl})$ than the control $(57.07 \pm 0.75 \mathrm{mg} / \mathrm{dl})$ group. The present findings are supported by Rahbar et al. (2014), who opined that the supplemental fat may

Table 3 Serum blood glucose level (mg/dl) (mean \pm SE) during peripartum period

\begin{tabular}{llc}
\hline Days pre-and postpartum & \multicolumn{1}{l}{ Blood glucose $(\mathrm{mg} / \mathrm{dl})$} & Treatment $(\mathrm{n}=30)$ \\
\cline { 2 - 3 } & Control $(\mathrm{n}=10)$ & $52.61 \pm 1.07^{\mathrm{aB}}$ \\
\hline-14 & $56.84 \pm 1.27^{\mathrm{aA}}$ & $67.63 \pm 0.56^{\mathrm{dB}}$ \\
0 & $64.80 \pm 1.14^{\mathrm{cA}}$ & $58.56 \pm 0.42^{\mathrm{bB}}$ \\
10 & $54.19 \pm 1.27^{\mathrm{aA}}$ & $58.61 \pm 0.45^{\mathrm{bB}}$ \\
20 & $55.08 \pm 1.03^{\mathrm{aA}}$ & $59.45 \pm 0.42^{\mathrm{cB}}$ \\
30 & $54.47 \pm 1.03^{\mathrm{aA}}$ & $59.37 \pm 0.48^{\mathrm{B}}$ \\
\hline
\end{tabular}

Note: Means having different superscripts (capital letter) within a row differ significantly $(\mathrm{P}<0.05)$.

Means having different superscripts (small letter) within a column differ significantly $(\mathrm{P}<0.05)$.

Table 4 Total serum cholesterol level $(\mathrm{mg} / \mathrm{dl})(\mathrm{mean} \pm \mathrm{SE})$ during peripartum period

\begin{tabular}{lll}
\hline Days pre-and postpartum & \multicolumn{2}{l}{ Total cholesterol $(\mathrm{mg} / \mathrm{dl})$} \\
\cline { 2 - 3 } & Control $(\mathrm{n}=10)$ & Treatment $(\mathrm{n}=30)$ \\
\hline-14 & $134.97 \pm 2.93^{\mathrm{b}}$ & $135.04 \pm 1.87^{\mathrm{b}}$ \\
0 & $119.67 \pm 2.23^{\mathrm{a}}$ & $123.43 \pm 1.61^{\mathrm{a}}$ \\
10 & $136.67 \pm 1.47^{\mathrm{bc}}$ & $142.18 \pm 1.44^{\mathrm{c}}$ \\
20 & $146.85 \pm 1.58^{\mathrm{cdA}}$ & $158.98 \pm 1.75^{\mathrm{dB}}$ \\
30 & $157.52 \pm 2.99^{\mathrm{eA}}$ & $179.83 \pm 1.98^{\mathrm{eB}}$ \\
overall & $139.14 \pm 2.06^{\mathrm{A}}$ & $147.89 \pm 1.79^{\mathrm{B}}$ \\
\hline
\end{tabular}

Note: Means having different superscripts (capital letter) within a row differ significantly $(\mathrm{P}<0.05)$.

Means having different superscripts (small letter) within a column differ significantly $(\mathrm{P}<0.05)$.

Table 5 Serum calcium level $(\mathrm{mg} / \mathrm{dl})($ mean $\pm \mathrm{SE})$ during peripartum period

\begin{tabular}{llr}
\hline Days pre-and postpartum & \multicolumn{2}{l}{ Serum Calcium $(\mathrm{mg} / \mathrm{dl})$} \\
\cline { 2 - 3 } & Control $(\mathrm{n}=10)$ & Treatment $(\mathrm{n}=30)$ \\
\hline-14 & $8.86 \pm 0.27$ & $8.97 \pm 0 . .20$ \\
0 & $8.62 \pm 0.15$ & $8.73 \pm 0.14$ \\
10 & $8.76 \pm 0.23$ & $8.89 \pm .0 .22$ \\
20 & $8.87 \pm 0.29$ & $8.97 \pm 0.17$ \\
30 & $8.94 \pm 0.25$ & $9.09 \pm 0.19$ \\
overall & $8.81 \pm 0.11$ & $8.93 \pm 0.08$ \\
\hline
\end{tabular}

Table 6 Serum phosphorus level $(\mathrm{mg} / \mathrm{dl})($ mean $+\mathrm{SE})$ during peripartum period

\begin{tabular}{llc}
\hline Days pre-and postpartum & \multicolumn{2}{c}{ Serum Phosphorus $(\mathrm{mg} / \mathrm{dl})$} \\
\cline { 2 - 3 } & Control $(\mathrm{n}=10)$ & Treatment $(\mathrm{n}=30)$ \\
\hline-14 & $5.39 \pm 0.18$ & $5.40 \pm 0.11$ \\
0 & $5.21 \pm 0.16$ & $5.15 \pm 0.10$ \\
10 & $5.31 \pm 0.19$ & $5.39 \pm .0 .08$ \\
20 & $5.40 \pm 0.21$ & $5.42 \pm 0.09$ \\
30 & $5.46 \pm 0.17$ & $5.50 \pm 0.12$ \\
overall & $5.35 \pm 0.08$ & $5.37 \pm 0.05$ \\
\hline
\end{tabular}


increase glucose production, which in turn may have a positive effect on LH release.

\section{Total cholesterol}

The mean serum total cholesterol level during peripartum periods in the control and treatment group cows are presented in table 4.

Mean serum total cholesterol level showed non-significant difference between group prepartum, at calving and on day 10 postpartum. But on day 20 and 30 postpartum, serum total cholesterol was significantly higher in treatment group than control group. While comparing the group wise overall mean serum total cholesterol concentrations. It was observed that the cows supplemented with bypass fat were having significantly $(\mathrm{P}<0.05)$ higher serum cholesterol value than the control cows $(147.89 \pm 1.79$ vs. $139.14 \pm 2.06 \mathrm{mg} / \mathrm{dl})$.

The mean serum total cholesterol values in the cows under both the groups significantly decreased on the day of calving from prepartum level. Thereafter, the values again increased in the subsequent days postpartum to reach the highest value at day 30 postpartum in both groups. Within both groups serum total cholesterol was significantly higher $(\mathrm{P}<0.05)$ on day 30 postpartum from other all stages studied. In control group serum total cholesterol level was non-significantly higher on day 20 postpartum than day 10 postpartum, but in the treatment group the trend was significant.

In the present study, the overall mean serum total cholesterol value in bypass fat supplemented group $(147.89 \pm 1.79 \mathrm{mg} / \mathrm{dl})$ was found to be significantly higher $(\mathrm{P}<0.05)$ than control group $(139.14 \pm 2.06 \mathrm{mg} / \mathrm{dl})$. The results can be substantiated by the observations of Ranjan et al. (2012), Singh et al. (2014), Grewal et al. (2014), Waghmare et al. (2016). Dietary fat increases circulating concentrations of cholesterol (Staples and Thatcher, 2005 and Grummer and Carrrol, 1991). However, some other previous researchers reported non-significant higher cholesterol level in fat supplemented group were Tyagi et al. (2010), Shelke et al. (2012a), Singh et al. (2014). While, Yadav et al. (2015) and Gnanasekar et al. (2016) observed the concentration of plasma total cholesterol was lower in bypass fat treated cows than the control cows.

The mean serum total cholesterol in cows under both the groups were found to be decreased on the day of calving from prepartum level, thereafter, with an increasing trends observed in both the groups corroborated with reports of Prakash and Tandon (1979), Saha et al. (1991), Guedon et al. (1999) and Yadav et al. (2015). Lactation probably also affect the level of plasma total cholesterol, which act as a fatty acid carrier in the form of cholesterol ester for milk synthesis, as a result there is gradual increase in plasma cholesterol level with advancing lactation (Theodore et al., 2015).
Higher cholesterol concentration is associated with better reproductive performance in high yielding dairy cows, as it acts as a precursor of steroid hormones (Son et al., 1996).

\section{Serum calcium}

The mean serum calcium level during peripartum periods in the control and treatment group cows are presented in table 5 .

In the present study, mean serum calcium level was nonsignificantly different between the groups and within both the groups at all stages studied are in agreement with the reports of Gowda et al. (2014) and Waghmare et al. (2016). The present findings indicated that bypass fat supplementation did not have any significant impact on serum calcium level during lactation in cows. The concentration of calcium in the blood was well within the normal physiological limits $(8-11 \mathrm{mg} / \mathrm{dl})$.

\section{Serum phosphorus}

The mean serum phosphorus levels during peripartum period in the control and treatment group cows are presented in table 6.In the present study, mean serum phosphorus level was nonsignificantly different between the groups and within both the groups at all stages studied is corroborating with the reports of Gowda et al. (2014) and Sahoo et al. (2016). The trend of mean plasma level of inorganic phosphorus obtained from prepartum to calving then up to day 30 postpartum period are in partial agreement with the findings of Dhami et al., (2005), Gowda, (2014) and Theodore et al., (2017).

\section{Conclusions}

In this study peripartum bypass fat supplementation did not show any beneficial effect on the uterine involution time and the interval from calving to first estrus occurrence. It is concluded that bypass fat improved energy balance that represented through significantly lower serum NEFA and higher glucose level in bypass fat supplemented group.

\section{Acknowledgements}

The authors thankfully acknowledged the financial support and facilities provided by RAJUVAS, Bikaner to carry out the research work.

\section{References}

Arieli A, Dicken U, Dagoni I, Spirer Y, Zamwel S (2008) Production and health of cowsbgiven monensin prepartum and a high-energy diet postpartum. J Dairy Sci 91:1845-1851

Bell AW (1995) Regulation of organic nutrient metabolism during transition from late pregnancy to early lactation. J Anim Sci 73: 2804-2819

Cerri RLA, Juchem SO, Chebel RC, Rutigliano HM, Bruno RGS, Galvao KN, Thatcher WW, Santos JEP (2009) Effect of fat source differing in fatty acid profile on metabolic parameters, fertilization, and 
embryo quality in high-producing dairy cows. J Dairy Sci 92:15201531

De Veth M, Bauman D, Koch W, Mann G, Pfeiffer A, Butler W (2009) Efficacy of conjugated linoleic acid for improving reproduction: A multi-study analysis in early-lactation dairy cows. J Dairy Sci 92: 2662-2669

Dhami AJ, Lakum PD, Patel PM, Panchal MT, Kavani FS (2005) Blood biochemical profile in relation to age and reproductive status of Holstein Friesian cattle reared under tropical climate. Indian J Anim Reprod 26(1): 34-38

Doepel L, Lapierre H, Kennelly JJ (2002) Peripartum performance and metabolism of dairy cows in response to prepartum energy and protein intake. J Dairy Sci 85: 2315-2334.

Drackley JK (2000) Use of NEFA as a tool to monitor energy balance in transition dairy cows. Illinois Dairy Days

Fahey J, Mee JF, Murphy JJ, O'callaghan D (2002) Effects of calcium salts of fatty acids and calcium salt of methionine hydroxy analogue on plasma prostaglandin F2á metabolite and milk fatty acid profiles in late lactation Holstein-Friesian cows. Theriogenology 58: 14711482

Galvao KN, Flaminio MJBF, Brittin SB, Sper R, Fraga M, Caixeta L, Ricci A, Guard CL, Butler WR, Gilbert RO (2010) Association between uterine disease and indicators of neutrophil and systemic energy status in lactating Holstein cows. J Dairy Sci 93: 2926-37

Garverick HA, Harris MN, Vogel-Bluel R, Sampson JD, Bader J, Lamberson WR, Spain JN, Lucy MC, Youngquist RS (2013) Concentrations of nonesterified fatty acids and glucose in blood of periparturient dairy cows are indicative of pregnancy success at first insemination. J Dairy Sci 96: 181-188

Ghosh PP, Roy Choudhury R, Bandopadhyay SK, Sanyal S, Haldar S, Ghosh BB (1991) Blood glucose and protein levels in crossbred cows during pregnancy. Indian J Anim Reprod 12(2): 165-166

Giuliodori MJ, Delavaud C, Chilliard Y, Becú-Villalobos D, Lacau-Mengido I, de la Sota RL (2011) High NEFA concentrations around parturition are associated with delayed ovulations in grazing dairy cows. Livest Sci 141: 123-128

Gnanasekar R, Singh M, Roy AK, Ajithakumar HM, Thakur S (2016) Plasma hormones, lipid profile and productive performance during early lactation in crossbred cows supplemented with prilled fat. Indian J Anim Nutr 33(4): 399-403

Goff JP, Horst RL, Jardon PW, Borrelli C, Wedam J (1996) Field trials of an oral calcium propionate paste as an aid to prevent milk fever in periparturient dairy cows. J Dairy Sci 79: $378-383$

Gowda AJS (2014) Studies on the influence of feeding bypass protein, bypass fat and propylene glycol on postpartum reproductive performance of dairy cattle. M.V.Sc. Thesis. Karnataka Veterinary, Animal and Fisheries Sciences University, Bidar, Karnatka

Grewal RS, Tyagi N, Lamba JS, Ahuja CS and Saijpaul S (2014) Effect of Bypass Fat and Niacin Supplementation on the Productive Performance and Blood Profile of Lactating Crossbred Cows under Field Conditions. Anim Nutr Feed Techn 14: 573-581

Grummer RR, Carrol DJ (1991) Effect of dietary fat on metabolic disorders and reproductive performance of dairy cattle. Review. J Dairy Sci 69: 3838-3852

Guedon L, Saumande J, Dupron F, Couquel C, Desbals B (1999) Serum cholesterol and triglycerides in postpartum beef cows and their relationship to the resumption of ovulation. Theriogenology 51(7): 1405-1415

Gutierrez CE, Pelton SH, Gilbert RO, Butler WR (2009) Effect of peripartum dietary energy supplementation of dairy cows on metabolites, liver function and reproductive variables. Anim Reprod Sci 112: 301-315
Hadiya KK (2006) Effect of supplementation of minerals and enzymes on postpartum fertility in triple crossbred cows. M.V.Sc. Thesis, A.A.U., Anand, Gujarat, India.

Jenkins TC, Palmquist DL (1984) Effect of fatty acids or calcium soaps on rumen and total nutrient digestibility of dairy rations. J Dairy Sci 67: 978-986

Kaczmarowski M, Malinowski E, Markiewicz H (2006) Some hormonal and biochemical blood indices in cows with retained placenta and puerperal metritis. Bulletin of the Veterinary Institute in Pulawy, 50: $89-92$

Khalil WA, El-Harairy MA, Abul-Atta AA (2012) Impact of dietary protected fat (Magnapac) on productive and reproductive performances of lactating Holstein cows. J Anim Poult Prod 3(10): 437-50

Kumar R, Sharma IJ, Agrawal RG (2000) Periparturient levels of certain organic and inorganic components in the blood of cows and buffaloes. Indian J Anim Reprod 21(2): 117-120

McNamara JP, Valdez F (2005) Adipose tissue metabolism and production responses to calcium propionate and chromium propionate. J Dairy Sci 88: 2498-2507

McNamara S, Butler T, Ryan DP, Mee JF, O’Mara FP, Butler ST, Anglesey D, Rath M, Dillon P, Murphy JJ (2003) Effect of offering rumenprotected fat supplements on fertility and performance in springcalving Holstein-Friesian cows. Anim Reprod Sci 79: 45-56

Miyoshi S, Pate JL, Palmquist DL (2001) Effects of propylene glycol drenching on energy balance, plasma glucose, plasma insulin, ovarian function and conception in dairy cows. Anim Reprod Sci 68: 29-43

Morrow DA, Roberts SJ, Mcentee K and Gray HG (1966). Postpartum ovarian activity and uterine involution in dairy cattle. J Am Vet Med A 149: 1596-1609.

NRC. (2001) Nutrient Requirements for Dairy Cattle, 7th rev. ed. National Academy of Sciences, Washington, DC

Prakash BS, Tandon RN (1979) A note on the late pregnancy and early lactation on blood serum cholesterol and total lipids of Holstein $x$ Tharparkar first lactation cows. Indian J Anim Sci 49: 308-309

Rahbar B, Safdar AHA, Kor NM (2014) Mechanisms through which fat supplementation could enhance reproduction in farm animal. Euro J Exp Bio 4(1): 340-348

Rajesh G, Singh M, Roy AK, Singh S (2014) Effect of prilled fat supplementation on milk yield, composition and plasma hormones in early lactation crossbred cows. J Bio Innov 3(4): 216-224

Ranjan A, Sahoo B, Singh VK, SrivastavaS, Singh SP, Pattanaik AK (2012) Effect of bypass fat supplementation on productive performance and blood biochemical profile in lactating Murrah (Bubalus bubalis) buffaloes. Trop Anim Health Prod 44: 1615-1621

Rukkwamsuk T, Wensing T, Geelen MJH (1998) Effect of over feeding during the dry period on regulation of adipose tissue metabolism in dairy cows during the periparturient period. J Dairy Sci 81: 29042911

Saha K, Roychoudhury R, Kanjilal BC, Bandopadhyay SK, Ghosh BB (1991) Serum cholesterol level in crossbred cows during prepartum, partum and postpartum period. Indian J Anim Reprod 12(2): 170172

Sahoo JK, Das SK, Sethy K, Mishra SK, Swain RK, Mishra PC, Satapathy D (2016) Effect of supplementation of mineral mixture and bypass fat on performance of crossbred cattle. J Anim Res 64: 611-618

Sato H (1978) Plasma glucose, lipids and mineral levels from 3 weeks before to 10 weeks after parturition in dairy cows. Jpn $J$ Zootech Sci 49: 333-338

Shelke SK, Thakur SS, Amrutkar SA (2012a) Effect of feeding protected fat and proteins on milk production, composition and nutrient utilization in Murrah buffaloes (Bubalus bubalis). Anim Feed Sci Techn 171: 98-107 
Shelke SK, Thakur SS, Shete SM (2012b) Productive and reproductive performance of Murrah buffaloes (Bubalus bubalis) supplemented with rumen protected fat and protein. Indian J Anim Nutr 29: 317323

Singh M, Sehgal JP, Roy AK, Pandita S, Rajesh G (2014). Effect of prill fat supplementation on hormones, milk production and energy metabolites during mid lactation in crossbred cows. Vet World 7: 384-388

Sivaraman T, Shanmugasundaram S, Arunachalam, S, Sivakumar T (2002) Blood profile of Jersey crossbred cows under different physiological stages. Indian J Anim Res 36(2): 114-117

Snedecor GW, Cochran WG (1994). Statistical Methods. $8^{\text {th }}$ edition, Oxford \& IBH Publishing Co., Calcutta.

Son J, Grant RJ, Larson LL (1996) Effects of tallow and escape protein on lactational and reproductive performance of dairy cows. J Dairy Sci 79: $822-830$

Staples CR, Thatcher WW (2005) Effects of fatty acids on reproduction of dairy cows. In: Garnsworthy PC, Wiseman, J. (Eds.), Recent Adv. Anim. Nut. Nottingham Univ. Press, Nottingham, UK, 229-25

Thatcher W, Bilby T, Bartolome J, Silvestre F, Staples C, Santos J (2006) Strategies for improving fertility in the modern dairy cow. Theriogenology 65: 30-44

Theodore VK, Panchal MT, Dhami AJ, Hadiya KK, Shah SV , Buhecha KV (2016) Whether peripartum nutritional supplementation influence the uterine involution and postpartum fertility in crossbred cows. Indian J Vet Sci Biotechn 52: 275-284
Theodore VK, Panchal MT, Dhami AJ, Parmar SC, Bhanderi BB and Chaudhary S (2017) Effect of bypass fat and minerals supplementation during transitional period on plasma levels of thyroid hormones, metabolites and postpartum fertility in crossbred cows. Indian J Vet Sci Biotechn 13(1): 1-8

Theodore (2015) effect of peripartum nutritional supplementation on uterine involution and postpartum fertility in crossbred cows. M.V.Sc Thesis AAU, Anand, India

Tyagi N, Thakur SS, Shelke SK (2009) Effect of feeding bypass fat supplement on milk yield, composition and nutrient utilization in crossbred cows. Indian J Anim Nutr 26(1): 1-8

Von Soosten D, Meyer U, Piechotta M, Flachowsky G, Danicke S (2012) Effect of conjugated linoleic acid supplementation on body composition, body fat mobilization, protein accretion, and energy utilization in early lactation dairy cows. J Dairy Sci 95: 1222-1239

Wadhwa M, Grewal RS, Bakshi MPS, Brar PS (2012) Effect of supplementing bypass fat on the performance of high yielding crossbred cows. Indian J Anim Sci 82(2): 200-203

Waghmare SP, Meshram RB, Dakshinkar NP, Pajai KS and Siddiqui MFMF (2016) Effect of supplementation of bypass fat on biochemical profile in dairy cows. Asian J Anim Sci 11(2): 111-114

Yadav G, Roy AK Singh M (2015) Effect of prilled fat supplementation on milk production performance of crossbred cows. Indian J Anim Nutr 32(2): 133-138

Zhang H, Wang Z, Liu G, He J, Su CH (2011) Effect of dietary fat supplementation on milk components and blood parameters of earlylactating cows under heat stress. Slovak J Anim Sci 44: 52-58 